\title{
A MASSZÁZS, MINT SZOLGÁLTATÁSI KATEGÓRIA MEGJELENÉSE AZ ÉSZAK-ALFÖLDI SZÁLLODÁK KÍNÁLATÁBAN
}

\section{Szerzők:}

Biró Melinda (PhD)

Debreceni Egyetem (Magyarország)

Elena Bendíková (PhD, Prof.)

Matej Bel University (Slovakia)

Michal Marko (Mgr.)

Matej Bel University (Slovakia)

Tütünkov-Hrisztov Jordan

Budapest Metropolitan Egyetem (Magyarország)

Lenténé Puskás Andrea $(\mathrm{PhD})$

Debreceni Egyetem (Magyarország)
Lektorok:

Müller Anetta (PhD, habil)

Debreceni Egyetem (Magyarország)

Fenyves Veronka ( $\mathrm{PhD}$, habil)

Debreceni Egyetem (Magyarország)

Első szerző e-mail címe:

biro.melinda@sport.unideb.hu

Biró Melinda, Elena Bendíková, Michal Marko, Tütünkov-Hrisztov Jordan és Lenténé Puskás Andrea (2019): A masszázs, mint szolgáltatási kategória megjelenése az Észak-alföldi szállodák kínálatában. Különleges Bánásmód, 5. (4). 21-32. DOI 10.18458/KB.2019.4.21

\section{Absztrakt}

Háttér: A masszázs wellness-turizmus fő (és az egyik legkedveltebb) szolgáltatási kategóriái közé tartozik, így nem véletlen, hogy a szállodák kínálatában megjelenik. Egyre több kutatás bizonyítja a masszázs hatékonyságát és használatának előnyeit a különféle sérülések, betegségek kezelésében, a fájdalomérzet, izomfeszültség és a szorongás csökkenésében és annak mérséklésében. Nemcsak hogy az egyészségre pozitívan hat, de fontos szerepe van a kikapcsolódásban, így nem véletlen, hogy a legkedveltebb wellness szolgáltatások egyike. E szolgáltatást a vendégek a fontos tényezők közé sorolják a desztináció választásban (Müller és Könyves 2006). Célkitűzés: Mivel az Észak-Alföldön az idegenforgalom szerepe fontos tényező, így a kutatásunkban a régió 3-5 csillagos szállodáiban néztük meg, hogy a kínálati elemek között milyen szerepet kap a masszázsszolgáltatás. 50 szállodát (18 három csillagos, 31 négy csillagos, 1 öt csillagos) vizsgáltunk meg kérdőív segítségével, valamint weblapjuk elemzésével a szolgáltatásaik és a kínálati elemek tekintetében. Eredmények: a vizsgált szállodák többségében a masszázsszolgáltatás, különböző mértékbe ugyan, de megtalálható. A leggyakrabban előforduló masszázstípusok a frissítő, vita-lizáló masszázs, a talpmasszázs, a svédmasszázs, az aromaterápiás masszázs és a relaxáló, stresszoldó masszázs, de emellett sokféle különleges masszázstípust kínálnak a szállodák a vendégeknek. Következtetések: nem csak az emberek üdülőhely megválasztását befolyásoló tényezőinél, de a szállodák kínálati elemeiben is megjelenik az élmény, a kényeztetés, az egészségtudatosság. 
Kulcsszavak: masszázsszolgáltatás, kínálati elem, turizmus, egészség

Diszciplina: turizmus, gazdaságtudomány, egészségtudomány

\begin{abstract}
Background: Massage is one of the main categories of wellness tourism and is one of the most popular, so it is no accident that it is included in the hotel offerings. Research proves the effectiveness of massage and its benefits in the treatment of various injuries, diseases, reduction of pain, muscle tension and anxiety. Not only does it have a positive effect on health, but it plays an important role in relaxation, so it is no coincidence that it is one of the most popular wellness services. Hotel guests include massage as an important factor in choosing a destination. Aims: Because of the importance of tourism in the Northern Great Plain, our research looked at the role that massage services play in the supply of elements in the region's 3-5 star hotels. We surveyed 50 hotels (18 three-star, 31 four-star, 1 five-star) through a questionnaire and website analysis for their services and offerings. Results: Our results showed that the majority of the examined hotels have massage services, although to varying degrees. The most common types of massage are refreshing, vitalizing massage, foot massage, Swedish massage, aromatherapy massage and relaxing, stress relieving massage, but there are also many special types of massage. Conclusion: The conclusion of our research is that experience, pampering, and health consciousness appear not only in the factors influencing people's choice of resort, but also in the offerings of hotels.
\end{abstract}

Keywords: massage service, supply element, tourism, health

Disciplines: tourism, economy science, health sciences

A belföldi, turisztikai célú többnapos utazások adata a 2008-2017-közi időszakot tekintve az utazás célja szerinti választás azt mutatják, hogy leginkább a szórakozás, pihenés (61\%) a fő utazási motívum (Biró és tsai, 2019; Fenyves és tsai, 2019). Az emberek a pihenés alatt szeretnének kikapcsolódni, ellazulni, feltöltődni, ezért a szolgáltatásokban is ezt keresik. Az Észak-Alföldön, az elmúlt években (2014 és 2017 között) a vendégellátásban nőtt a férőhelyek száma, emellett az előrejelzési trend is azt mutatja, hogy ez továbbra is növekedni fog (Biró és tsai, 2019). Ez számos tényezőtől függ, de ez egyik legjelentôsebb motívum, hogy mennyire népszerü a régió a turisták körében. Emellett ugyancsak lényeges, hogy a kínált szolgáltatások vonzóak legyenek az utazók számára (Hidvégi és tsai, 2015; Biró és Müller, 2017; Lenténé és tsai, 2018).

A szállodák ma már nem csupán az évi rendes főnyaralás helyszínei, hanem az általános jó közérzet, a test és a szellem egészsége megőrzésének helyszínévé is vált. Ennek következtében szükség- szerûvé vált a kereskedelmi szálláshelyek mennyiségi és minőségi kínálatának javítása (Fenyves és tsai, 2014; Fenyves és tsai 2016; Lenténé és tsai, 2019; Hidvégi és tsai, 2019).

Az egészséges életmódhoz tartozón szolgáltatások - mint amilyen a masszázs -, hozzájárulnak a vendégek teljes körű kikapcsolódásához (Müller és Bácsné, 2018).

A masszázs mellett számos stresszoldó módszer és technika (pl. a mindfullness) megjelenik a turisztikai motivációban és ezzel együtt a kínálatban is (Lengyel 2015, 2019; Lengyel és tsai 2018; Lengyel és Kalmárné 2018). Mivel az egészségre való törekvés az üdülések során egyre inkább megfigyelhető, ezek hatása a turisztikai desztinációk megválasztásakor is érvényesül, sőt a szolgáltatások preferencia rendszerében is megjelenik (Szira és Lajos, 2005). A szállodák szolgáltatásainál tehát fontos, hogy mit kínálnak a vendégeik számára (Müller és tsai, 2016), hiszen számukra jó esélyt jelenthet a desztinációk versenyében. 
Korábbi kutatásaink eredményei (Müller és tsai, 2016) is ezt bizonyították, hogy a termékfejlesztés fontossága elengedhetetlen a turisztikai szektor gyors növekedésének következtében pedig rendkívül fontos a további folyamatos fejlesztés (humánerőforrás, információs, honlap, kínálati elem) ahhoz, hogy megbirkózhassanak a turizmus növekvő követelményeivel.

Ma Magyarországon a szállodáknak a szabadidős szolgáltatásokkal kapcsolatosan a szállodák a minősitő rendszerben kötelező elő́ríśsok nem szerepelnek, csak választási alternatívák a pontgyüitésre. Jelenleg a szállodákat egy kategóriánként egységes európai minősítő követelményrendszer alapján sorolják be egytől öt csillagig.

A 239/2009. (X. 20.) Kormányrendelet szabályozza a kereskedelmi szálláshelyek üzemeltetési feltételeit és ez rendelkezik a szállodák kötelező minősítésérôl. Minél több csillaggal rendelkezik egy szálloda, annál jobb szolgáltatásokat kínál a vendégek számára.

Egy korábbi (45/1998. (VI. 24.) IKIM) rendelet értelmében a wellness szállodáknál találkoztunk olyan követelményekkel, mely előírta, hogy a szálloda számára milyen különféle szolgáltatásokat kellett nyújtani (például: 4 féle szépségápolási szolgáltatást, vagy legalább 6 féle masszázs, relaxációs és egyéb közérzetjavító - vizes és száraz - szolgáltatást kell kínálnia). Ez a korábbi rendelet, mint látható kitért a masszázsszolgáltatásra is.

A jelenlegi kormányrendelet érvénybe lépésével módosult a szabályzat: egységes európai követelménynek megfelelően pontszámokkal jelölik az egyes feltételeket, és szolgáltatásokat aminek meg kell felelni, csillagszámtól függően. A szabadidős tevékenységek meghatározásánál a szállodáknak a minősítő rendszerben kötelezô előírások nem szerepelnek, csak választási alternatívák a pontgyüjtésre. Itt kapnak helyet a korábbi wellness szállodák kívánalmai is, mint a masszázs. Így a masszázsszolgáltatással kapcsolatosan jelenleg nincs konkrét kitétel, úgy mint korábban, csak annyi, hogy ha ilyen szolgáltatást kínálnak a vendégek számára, akkor a helység méretének minimum 10 négyzetméteresnek kell lennie. A masszázsszolgáltatásért a szálloda két pontot kaphat, de maximum csak hatot gyújthet a kabinok számának megfelelően. Mint látható nem a masszázstípusok számától függ a pontszám, hanem a helységek számától.

\section{A masszázs, mint szolgáltatási kategória}

Az egészség, mint érték egyre fontosabb szerepet kap az ember életében (Horkay és tsai, 2018), mely nem csak a rendszeres testmozgás igényében jelentkezik (Juhász és tsai, 2015; Kopkáné és tsai, 2015), hanem a szabadidő eltöltésében is (Szira és Lajos 2005; Müller és Kerényi 2009; Boda és tsai, 2015; Bodolai és tsai, 2016; Biró és Müller 2017; Mező és Mező 2017; Müller és tsai 2019; Laoues és tsai. 2019 a,b,c; Fehér és tsai. 2019). A masszázs nem csak a szabadidő hasznos eltöltéséhez, de az egészséges életmódhoz is hozzátartozik - így nem meglepó, hogy egyre inkább megjelenik a wellness trendek között is és a szállodák, fürdők kínálatában is egyre növekvő szerepet kap.

A masszázs egyre egzotikusabb és különlegesebb változataival várják a vendégeket a látogatókat. $\mathrm{A}$ kínálati trendekben megjelenő élménynyújtás, az egyediség, az indivídum szerepe, a helyi specialitásokhoz való igazodás, a keleti és a nyugati irányzatok ötvöződése, a komplexitás (Fónagy, 2009) a masszázstípusok megjelenésében is megfigyelhető.

Mivel a masszázs a wellness-turizmus fő szolgáltatási kategóriái közé tartozik, így nem véletlen, hogy a masszázs-szolgáltatást a szállodák kínálatában a vendégek a fontos tényezők közé sorolták (Árpási, 2014) azon tényezőkkel együtt, hogy a hotelben legyen medence, lehessen szaunázni és legyen biztosítva az orvosi felügyelet.

Ennek ellenére egy másik hazai kutatás (Fodor é Szilágyi 2014), mely az egészségmegőrzés és a wellness fogyasztói megítélését vizsgálta azt mutatta ki, hogy a rendszeres masszázs sajnos a legkevésbé jelenik meg az egészségmegőrzésben és az egészségmegőrző tevékenységekre fordított kiadások közt is elenyésző a szerepe. Ennek oka talán az lehet, hogy az üdülőhely megválasztását befolyásoló tényezóknél nem az egészség kategóriába illesztik a masszázst, hanem az élmény, kényeztetés közé (Árpási, 2014).

Árpási (2014) felmérése szerint a legkedveltebb wellness szolgáltatások a termál-, élményfürdő, szauna és a masszázs. A wellness-kínálat szolgáltatáselemeinél a fogyasztói megítélésében a víz és a 
szauna szolgáltatás után a masszázs következett. A vendégek a wellness-kínálat szolgáltatáselemeinél a masszást fontosnak tartják (Árpási, 2014).

\section{A masszázs hatékonysága}

Egyre több kutatás bizonyítja a masszázs hatékonyságát és használatának előnyeit a különféle sérülések, betegségek kezelésében, a fájdalomérzet, izomfeszültség és a szorongás csökkenésében és annak mérséklésében. Hatékonysága bizonyított a térd degeneratív ízületi gyulladása esetén, annak kezelésében és rehabilitációjában (Perlman és tsai, 2006; Atkins és Eichler, 2013). A vizsgálatok jelentős javulást mutatnak a fájdalom mértékének csökkenésében, az ízületi mozgáskiterjedésben és a mozgástartomány fokban, valamint számos további fizikai funkcióban is (Crane és tsai, 2012, Csörgő és tsai, 2013).

További kutatás igazolta, hogy tradicionális thai masszázs hatására pozitív változás következett be: a pulzusszám, a fájdalom intenzitása, az izomfeszültség és a szorongás csökkenésében, valamint a hajlékonyságban. Ezzel együtt a szubjektív fájdalomérzet szignifikáns csökkenést mutatott a szorongással és az izomfeszüléssel együtt, miközben a kontrollcsoport eredményei nem mutattak szignifikáns változást (Buttagat és tsai 2011).

Kombinált, több masszázstípusból álló, masszázsterápia hatására javulás következett be az ízületi mozgásterjedelmet, a szubjektív fájdalomérzetet, a fizikai- és mentális egészségi állapotában 60 év feletti nők körében már öt alkalmat követően is (Csörgő és tsai, 2013)

A masszázsterápiák szerepe a kiegészítő és alternatív gyógyászatban is egyre inkább megfigyelhető (Hymel és Rich, 2013). Gyógyír a mozgásszervi problémákra, a krónikus gyulladásos betegségekben, például ízületi gyulladás vagy izomsorvadás esetén is. Alkalmazzák fájdalomcsillapításra, váz- és izomrendszeri megbetegedések kezelésére, sport1sérülések rehabilitációjára, sőt egyre fontosabb szerepet kap a pszichológia területen (Hymel és Rich, 2013). Bizonyítottan csökkenti a stresszt, a szorongást és a depressziót, sőt segít a relaxációban és támogatja a jó közérzet elérését (Tidus, 2000; Robertson és tsai, 2002; Moyer és tsai, 2004; Field és tsai, 2004; Field és tsai, 2007; Krohn és tsai, 2010).

\section{MÓDSZER}

Kutatásunk során a masszázs szolgáltatásokra koncentráltunk. Célunk megvizsgálni, a masszázstípusok megjelenését az Észak-alföldi régió 3-5 csillagos szállodáinak szolgáltatásaiban, kínálati elemeiben. A kínálat elemzése volt a célunk.

\section{Minta}

A kutatásban 50 szállodát (18 három csillagos, 31 négy csillagos, 1 öt csillagos) vizsgáltunk meg kérdőív segítségével, valamint weblapjuk elemzésével a szolgáltatásaik és a kínálati elemek tekintetében. Az Észak-alföldi régióra tekintve a minta reprezentatív, hiszen minden 3 csillagos és a fölötti szálloda bekerült a vizsgálatba.

\section{Eszközök}

A kvantitatív eljárás során előtesztelt kérdőívet alkalmaztunk, melyben számos szolgáltatás felmérése szerepelt így a masszázstípusok felmérése csak egy kis részét képezték a komplex vizsgálatnak. Az alábbi témakörök kaptak helyt a kérdőívben: az egészségmegőrzés lehetőségei, wellness szolgáltatások, sport és szabadidős valamint gyógyászati szolgáltatások megjelenése a szállodák kínálatában.

Jelen tanulmányunkban kizárólag a masszázstípusok kínálati elemeit mutatjuk be.

\section{Eljárás}

Azokban az esetekben, ahol a szállodák nem töltöttök ki az adott kérdést, vagy a megadott masszázstípus száma nem egyezett a részletes felsorolással, ott még az honlapos elemzést alkalmaztuk. A wellness szolgáltatások árlistáit elemezve jutottunk további adatokhoz. Az adatfelvételre 2018-ban került sor.

\section{Eredmények}

A vizsgált szállodák 84 \%-ban van masszázsszolgáltatás. Átlagosan 6,14 masszázstípus fordul elő 
(szórás 5,2), míg a szállodák 16\%-ában nincs ilyen jellegű kínálat. Az ötven szállodában összesen 48 féle masszázstípust kínálnak a vendégek számára. Egy öt csillagos szálloda van a régióban, ahol 9 féle masszázsszolgáltatást kínálnak a vendégeknek. A négy csillagos szállodákban átlag 7,35, míg a három csillagosban átlag 4,16 masszázstípust ajánlanak a vendégeknek. A legtöbb masszázskínálat 22 féle masszázstípus volt az egyik szállodában, de 12 szállodánál is 10 fölötti volt a kínálat típusa (1. táblázat).

A leggyakrabban előforduló masszázstípusok a frissítô, vitalizáló masszázs (62\%), a talpmasszázs (58\%), a svédmasszázs (56\%), az aromaterápiás masszázs $(50 \%)$, a gyógymasszázs (50\%) és a relaxáló, stresszoldó masszázs (50\%).

A masszázsfajták vizsgálatakor érdemes megemlíteni, hogy az elnevezés alatt gyakran hasonló tartalom jelenik meg, hiszen a svéd masszázs, mely az alap masszázsfajták egyike ugyancsak a tipikus, lazító, frissítő masszázsfajtához tartozik.

Az egyes masszázsok hatásai közül leginkább, a frissítés, vitalizálás, relaxáció, a stressz elűzése a legfontosabb a fizikai hatásokon felül (mint amilyen az izmok ellazítása, a vérkeringés fokozása, valamint a méregtelenítés). Ebből a szempontból nehéz megvizsgálni a kínálatot, hiszen egy masszázs során a hatás összetetten jelentkezik, valamint számos masszázstípusnál kombinálják kiegészítő eszközökkel, olajokkal, herbáriával így hatása nem különíthető el. A talpmasszázsnál például a kínálatban megjelent többféle formában ez a masszázstípus frissítő talpmasszázsként, kényeztető talpmasszázsként és relaxáló talpmasszázsként.

Ennek ellenére, ha mégis megpróbálunk különbséget tenni a masszázstípusok hatásai között, akkor kiemelnénk a gyógymasszázst. A gyógymasszázst nem orvos végzi, hanem erre szako- sodott gyógymasszőr vagy gyógytornász, gyógyító, rehabilitációs céllal. Mivel az Észak-alföldi régió egészségpotenciálja kiemelkedő, így nem meglepő, hogy a szállodák felének $(50 \%)$ kínálatában is megjelenik ez a típus.

Itt érdemes megemlíteni az orvosi masszást, ami a szállodák további 8\%-ánál volt megtalálható. Ez mindössze annyiban különbözik a gyógymasszázstól, hogy a rövidebb idejű masszázskezelést egyéb gyógykezeléssel együtt írja fel az orvos, így ezekben a szállodákban további kezelésekre is lehetőség van.

Az üdülésre, pihenésre vágyó vendégek körében a relaxáció, a felüdülés kiemelt célként szerepel, így nem véletlen, hogy ez a régió szállodáinak kínálatában is megjelenik. A szállodák 50\%-ában megtalálható és a következő kulcsszavakkal hirdetik a masszázst: „,relaxáló masszázs, hangulatjavító maszszázs, stresszoldó masszázs”.

A vizsgált szállodák kínálatban 20\%-ban volt cellulit masszázs, melynek hatásai ugyancsak összetettek. Egyfelől szépségápolási célzatú - hisz a narancsbőr megszüntetésére irányul, másfelől pedig egészség célzatú. Mivel a cellulit hátterében számos egyéb ok mellett (táplálkozási problémák, mozgáshiány) leggyakrabban a nyirokrendszer elégtelen működése áll, így a masszázs során olyan erőteljes mozdulatokkal dolgoznak, mely célja a zsírsejtek összetörése, a kapillárisok aktiválása, értágító hatás kiváltása, a vérkeringés javítása, hogy ezáltal felgyorsítsák a sejtek anyagcseréjét. A cellulit maszszázs hatása fokozható fahéj hatóanyagú masszázs olajjal, valamint a köpölyözéssel. A gumiköpöly alkalmazása a vákuumhatás kedvezô élettani hatásait használja ki.

A szállodák közül egyben hirdettek külön köpölyös masszázst, míg ugyancsak egyben hirdettek külön narancs-fahéj masszázst is.

1. táblázat A masszáas szolgáltatások megosz̨lása a 3-5 csillagos szállodák kinálatában (forrás: a Sz̨erzők)

\begin{tabular}{|c|c|c|c|c|}
\hline \multicolumn{2}{|c|}{ szálloda } & 3 csillagos & 4 csillagos & 5 csillagos \\
\hline \multirow{4}{*}{ masszázsszolgáltatás } & & & & \\
\hline & $\mathrm{db}$ & 75 & 228 & - \\
\hline & átlag & 4,16 & 7,35 & 9 \\
\hline & szórás & 4,17 & 5,63 & - \\
\hline
\end{tabular}


A szállodák kínálatában a cellulit masszázs 20\%ban volt jelen, cellulit, alakformáló, vagy karcsúsító masszázs néven. További 14 \%-ban nyirok maszszázs, méregtelenítő nyirokmasszázs, 2\%-ban méregtelenítő masszázs, és további 2\%-ban pedig kötőszöveti masszázs elnevezéssel találkoztunk (1. ábra).

Egy szállodában kínáltak ayurvedikus masszást, mely egy olyan személyre szabott kezelés, amit a holisztikus gyógyászathoz sorolnak. Az anti-aging masszás is egy újfajta kínálati elemként jelent meg, melynek célja a bőrfiatalítás, a ráncok kialakulásának megelőzése (1. ábra).

A reflexmasszázs hatását tekintve ugyancsak összetett masszázstípus, hiszen a reflexpontok masszírozásával, nyomásával befolyásolni lehet a hozzájuk tartozó szervek működését, energiaellátását. A reflexmasszázs előnyeként említik továbbá, hogy beindítja a szervezet öngyógyító folyamatait, serkenti a vér- és a nyirokkeringést, a tápanyagellátást és a méregtelenítést, harmonizálja a működést, stresszoldó hatású (1. ábra).

A masszázskínálatban az egész test kezelésén túl egyes testrészek masszírozásai is megjelenik. Ezek közül leginkább a talpmasszázs, ami a szállodák 58\%-ában szerepelt a kínálatban, míg a hátmasszázs a legkevésbé 6\%-ban.

A fej, arc, és nyak 26\%, míg kizárólag az arc masszírozása 12\%-ban szerepelt a kínálati elemek között (2. ábra).

A svédmasszázs az a lazító, frissító fajta alapmasszázs melyet a legtöbb szállodában (56\%) megtalálunk a kínálatban. Emellett viszont megjelennek a Távol-keleti, ôsi, tradicionális masszázsfajták, mint amilyen az Indiai testmasszázs (4\%), a Shi-Tao (4\%) és a Tibeti hangmasszázs (4\%).

$\mathrm{Az}$ egyik legősibb, és legnépszerűbb keleti masszázs, mely hazánkban is régóta jelen van a Thai masszázs, így nem meglepó, hogy a szállodák kínálatában is elókelő helyen szerepel (14\%). A többi masszázstól eltérően ennél a típusnál nem használnak olajat, vagy krémet. A technikájában pedig ugyancsak eltérô, hiszen ennél a típusnál az akupunktúrás pontokat ingerlik, pontnyomással, sőt nyújtó gyakorlatokat is tartalmaz a mozgásanyaga. További különlegessége, hogy a masszőr nemcsak tenyérrel, de ujjheggyel, térddel, talppal és könyökkel is masszíroz.

1. ábra: a masszázskezelések hatás szerinti százalékos értékei az Észak-alföldi (3-5 csillagos) szállodák kinálatában (Forrás: a Szerzőo)




KÜLÖNLEGES BÁNÁSMÓD, V.ÉVF. 2019/4.

2. ábra: a masszázskezelések testrészek szerinti csoportositása az Észak-alföldi (3-5 csillagos) szállodák kinálatában (Forrás: a Szerzőke)

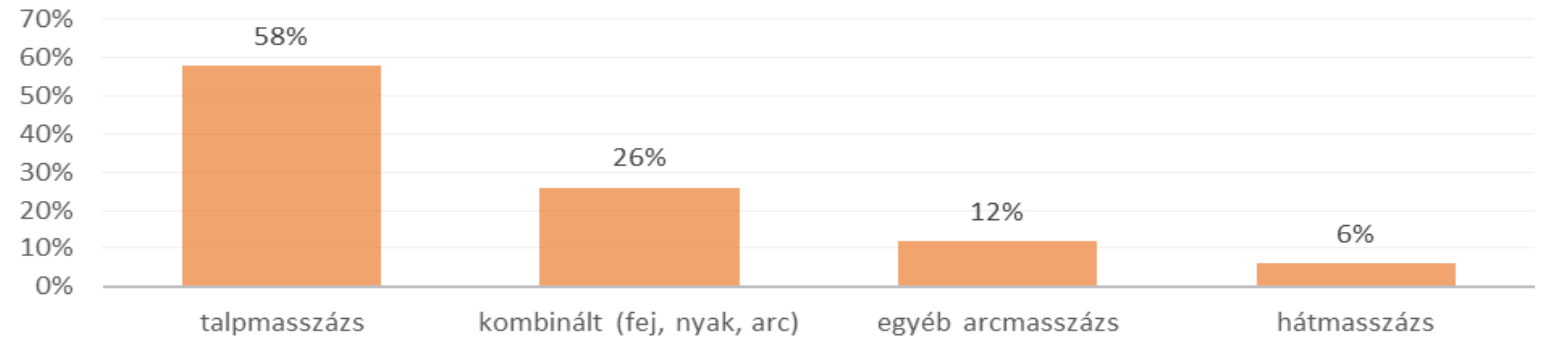

A Shiatsu masszázs a masszázs trendek között egyre inkább előtérbe kerül, de ennek ellenére a vizsgált szállodákban még kis mértékben találjuk meg $(6 \%)$, mindössze három szállodánál. A Shiatsu masszázs egy akupresszúrára épülő olyan keleti masszázsfajta, ami abban különbözik az ed- digiektől, hogy az ujjakat használják a masszírozás során a tenyér helyett, így stimulálva a meridián pontokat. Egy szállodánál találtunk Finn, és egynél Hungarikum masszázst a kínálati elemek között (3. ábra).

3. ábra: a különleges massqázskęelések elöfordulása az Észak-alföldi (3-5 csillagos) szállodák kinálatában (Forrás: a Szeræộk)

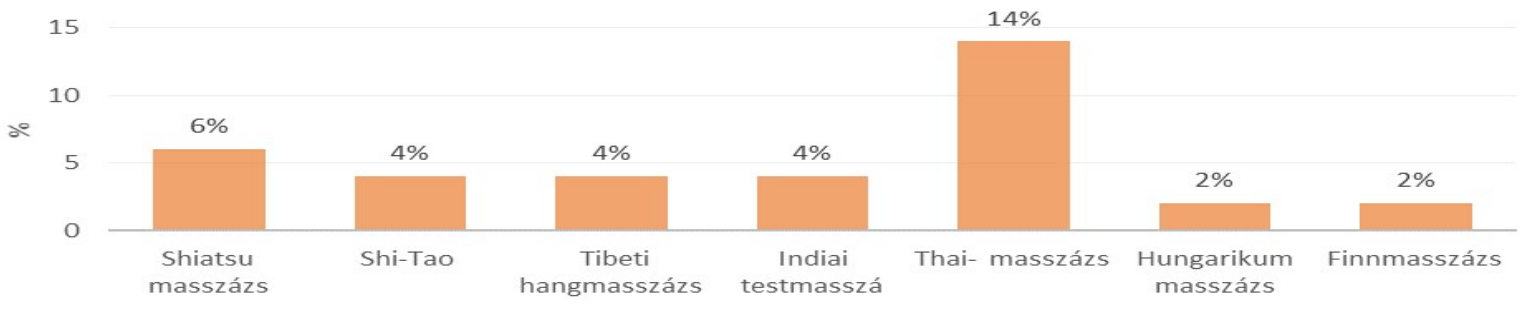

A masszázskínálatban olyan masszázstípusok is megjelentek, melyekhez különleges eszközöket alkalmaznak mely segíti, kiegészíti a kezelést. Egyik ilyen volt a lávaköves masszázs, melyben felmelegített, valamint váltakozó hőmérsékletű (hideg-meleg) a testre helyezett köveket alkalmaznak. 18\%-ban jelent meg a kínálatban a lávaköves, és 2\%-ban a jádeköves masszázs.

A hidromasszázs a szállodák 16\%-ában volt jelen a kínálatban. Ez a fajta masszírozási technika nem más, mint a víz és a levegő megfelelő összhangjával elért, vérkeringést fokozó masszázs. A masszírozást a meleg víz és a levegő keverékéből álló erōteljes vízsugár végzi. Egyéb eszközös típusok is megjelentek a kínálatban, mint például a bambuszrúd masszázs (4\%), mely során különböző hosszúságú olajozott bambusz rudak segítségével nyújtanak felüdülést a vendég számára. A labdacsos masszásnál $(2 \%)$, speciális gyógynövényekkel és füszerekkel töltött kis ladbacsokat (zsákokat) alkalmaznak, melyből forró gőz hatására kioldódó illóolajok hatékonyságát társítják a kezeléshez. A szárazkefe masszázsnál (2\%), pedig egy durva kefével dörzsölik végig az egész testet, mely eltávolítja az elhalt hámsejteket a bőr felszínéről, majd további szépségápolási vagy masszázstechnikával kombinálják a kezelést. A Kneipp féle taposó masszázs (2\%) különlegessége pedig, hogy a vendégek egy taposóban sétálnak, ahova lekerekített köveket helyeznek. A kövek masszírozása mellett a hideg és meleg hatás változtatásával további előnyös hatást lehet elérni (lásd: 4. ábra). 
4. ábra az eszközös masszázskę̧éések elöfordulása az Észak-alföldi (3-5 csillagos) szállodák kinálatában (Forrás: a Szerző)

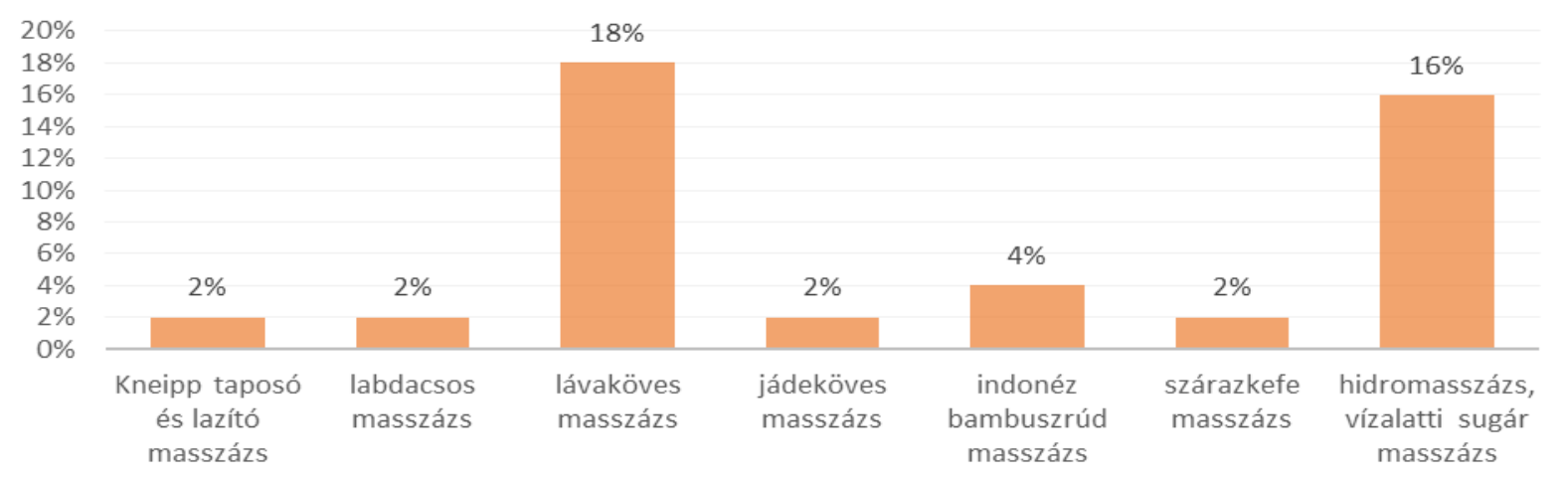

A masszázs által kifejlett hatások növelése érdekében különféle illóolajok, herbáriák, alkalmazása is gyakori. Míg egyes hatóanyagok a cellulit masszázs kiegészítő kellékei, pl a fahéj, vagy a pirospaprika pakolás, addig némelyik a stresszoldást, míg más a bőr fiatalítását segíti elő. A vizsgált szállodákban sokféle kínálattal találkoztunk. Az aromaterápiás kezelések voltak többségben melyet aromamasszázs, aromaolajos masszázs (50\%) néven is hirdettek. Találkoztunk forró olajos herbál masszázzsal (4\%), és ezen felül külön gyógyfüves masszázs $(6 \%)$ is szerepelt a kínálatban, mely nem azonos az előzőekkel. A labdacsos masszázst már korábban említettük, de itt is szükségesnek tartjuk, hiszen itt is gyógyfüveket alkalmaznak a maszszírozás során, csak annak felhasználási módja különböző.

Ha mindezeket összesítjük, akkor az aromás, herbáriás masszázstípusok a szállodák több mint felénél (72\%) megtalálhatók. A csokoládé (28\%) és a méz (18\%) masszás ugyancsak több szálloda kínálatában megjelent, hasonlóan a rózsaolajos (8\%), és a tengeri sós (4\%) masszázshoz (5. ábra).

5. ábra: az illóolajos, herbáriás masszázskezelések elöfordulása az Észak-alföldi (3-5 csillagos) szállodák kinálatában (Forrás: a Szerzoook)

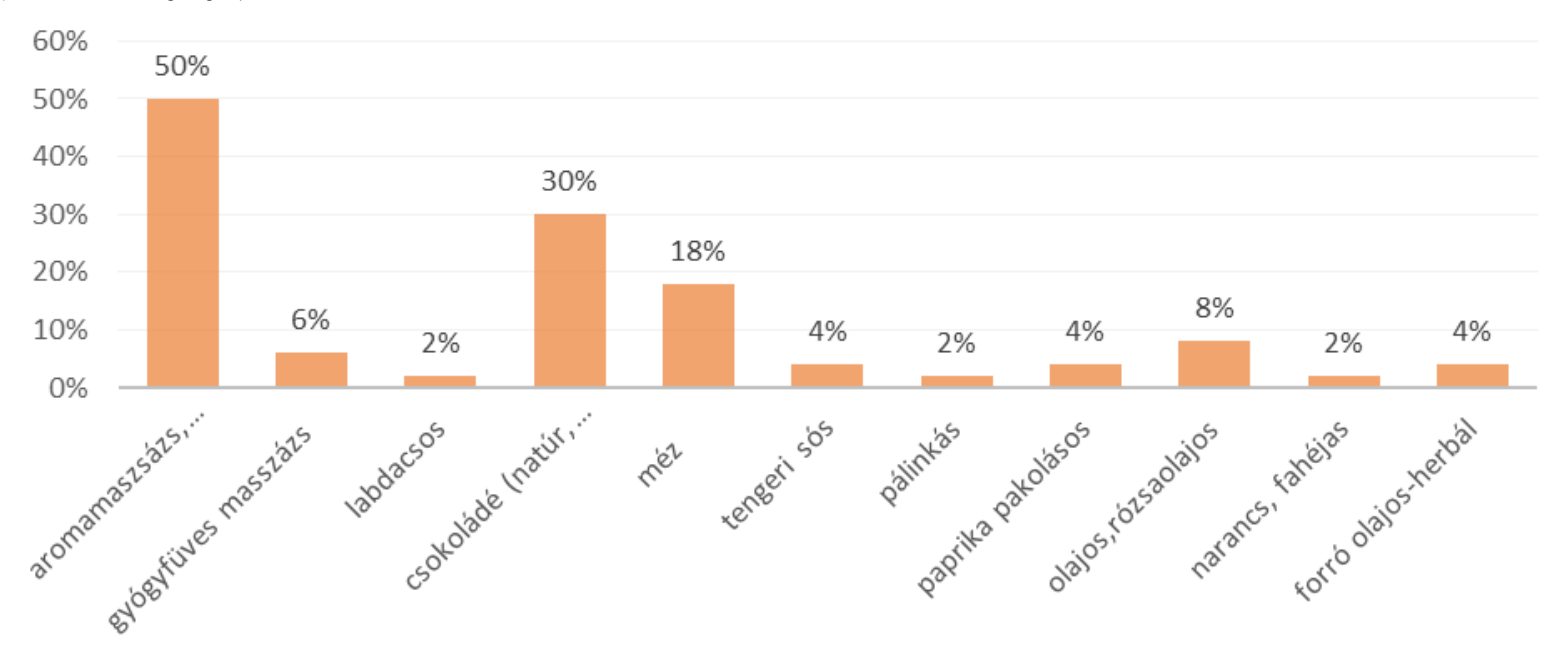




\section{Megvitatás}

Eredményeink azt mutatták, hogy a szállodák a kínálatbővítésében a masszázs is helyet kapott. Ez nem véletlen, hiszen egyfelól a kínált szolgáltatások teszik vonzóvá a szállodát az oda érkezők számára (Hidvégi és tsai, 2015; Biró és Müller 2017; Lenténé és tsai, 2018). Mivel mára a szállodák szerepe is változott és már nem csupán az évi rendes fônyaralás helyszínei, hanem az általános jó közérzet, a test és a szellem egészsége megőrzésének helyszínévé is vált, így ennek következtében szükségszerűvé vált a kereskedelmi szálláshelyek mennyiségi és minőségi kínálatának javítása (Lenténé és tsai, 2019; Hidvégi és tsai, 2019). A masszázskínálatban azt mondhatjuk, hogy a szállodák többségében van ilyen típusú szolgáltatás és a leggyakrabban előforduló masszázstípusok a frissító, vitalizáló masszázs, a talpmasszázs, a svédmasszázs, az aromaterápiás masszázs, gyógymasszázs és a relaxáló, stresszoldó masszázs, de emellett sokféle különleges masszázstípust kínálnak a szállodák a vendégeknek. A masszázs által kifejlett hatások növelése érdekében az illóolajok, a herbáriák, alkalmazása is gyakori, melyek közül a különféle aromaterápiás kezelések fordulnak elő leginkább a szállodák kínálatában, de a csokoládé-, és a mézmasszás ugyancsak több szálloda kínálatában megjelent.

\section{Konklúziók}

Kutatásunk során a masszázs szolgáltatások vizsgálatára vállalkoztunk. Célunk a masszázstípusok megjelenésének vizsgálata volt az Északalföldi régió 3-5 csillagos szállodáinak szolgáltatásaiban, kínálati elemeiben. Felmerült bennünk a kérdés, hogy a szállodák milyen mértékben kínálnak bizonyos szolgáltatásokat, mint például a masszázs a vendégeik számára és hogy azoknak milyen típusai figyelhetők meg a kínálati elemként.

Összegzésként azt mondhatjuk, hogy az egészséges életmódhoz tartozón szolgáltatások, mint amilyen a masszázs, hozzájárulnak a vendégek teljes körű kikapcsolódásához, a pihenéshez, és felüdülésükhöz. Mivel ez a turisztikai desztinációk megválasztásakor is érvényesül (Szira és Lajos, 2005), ezért a szállodák szolgáltatásainál fontos, hogy mit kínálnak a vendégeik számára (Müller és tsai, 2016). A kínálati trendekben megjelenő élménynyújtás, az egyediség, az indivídum szerepe, a helyi specialitásokhoz való igazodás, a keleti és a nyugati irányzatok ötvöződése, a komplexitás (Fónagy, 2009) a masszázstípusok megjelenésében is megfigyelhető, melyet az eredményeink is alátámasztanak. Ezeket a kínálati elemeket amennyiben a turisztikai szolgáltató megjeleníti az általa kínált csomagokban vagy rendezvényekben (Mezó, 2012), segíti a vendégelégedettség növelését (Kerényi, 2009, Müller és tsai, 2009, 2016).

A publikáaió elkészitését az EFOP-3.6.2.-16-201700003 számú projekt támogatta. A projekt az Európai Unió támogatásával, az Európai Szociális Alap társfinanszírozásával valósult meg.

\section{IRODALOM}

Árpási, Z. (2014). Wellness turisztikeai szolgáltatások fejlesztésének lehetöségei a dél-alföldi régióban. Doktori értekezés.

Atkins, D.V. \& Eichler, D. A. (2013). The effects of self-massage on osteoarthritis of the knee: a randomized, controlled trial. International Journal Of Therapeutic Massage \& Bodywork, 6 (1), 4.

Atkins, D. \& Eichler, D. (2013). The Effects of Self-Massage on Osteoarthritis of the Knee: a Randomized, Controlled Trial. International Journal of Therapeutic Massage Bodywork. 6(1). 4-14.

Bijur, P.E., Silver, W. \& Gallaghe, E.J. (2008). Reliability of the Visual Analog Scale for Measurement of Acute Pain. Acadenic Emergency Medicine. DOI: 10.1111/j.1553-2712.2001.tb01132.x

Bíró, M. \& Müller, A. (2017). Aktív pihenés, rekreáció $=$ Active relaxation, recreation. In Dobos, Anna, Mika, János (szerk.). Természeti és kulturtörténeti értékek Eger térségében $=$ Natural and cultural beritage in the Eger Region. Eger, Líceum Kiadó.

Biró, M., Tatár, A., Pucsok, J.M., Lenténé, P.A., Mikhárdi, S., Hidvégi, P. \& Molnár, A. (2019). $\mathrm{Az}$ Észak-alföldi régió szállodáinak egészségturisztikai trendjei. In Balogh, László (szerk.) Sokol- 
dalú sporttudomány. Debreceni Egyetem Sporttudományi Koordinációs Intézet, Debrecen. 9-20.

Boda, E., Honfi, L., Bíró, M., Révész, L., \& Müller, A. (2015). A szabadidő eltöltésének és a rekreációs tevékenységek vizsgálata egri lakosok körében. Acta Academiae Paedagogicae Agriensis Nova Series: Sectio Sport. 49-62..

Bodolai, M., Lívják, E., Boda, E. \& Bíró, M. (2016). A jóga hatása a szervezetre, szerepe a stresszkezelésben. Acta Academiae Paedagogicae Agriensis Nova Series: Sectio Sport. 51-67..

Buttagat, V., Eungpinichpong, W., Chatchawan, U. \& Kharmwan, S. (2011). Therapeutic effects of traditional Thai massage on pain, muscle tension and anxiety in patients with scapulocostal syndrome: a randomized single-blinded pilot study. Journal of Bodywork \& Movement Therapies, 15. 1523.

Clarkson, H.M. (2012). Musculoskeletal Assessment: Joint Motion and Muscle Testing. Williams \& Wilkins, Baltimore. 17-532.

Crane, J.D., Ogborn, D.I, Cupido, C., Melov, S., Hubbard, A., Bourgeois, J.M. \& Tarnopolsky, M.A. (2012). Massage Therapy Attenuates Inflammatory Signaling After Exercise-Induced.

Csörgő, T., Bíró, M., Kopkáné, P.J. \& Müller, A. (2013). Masszázsterápia hatásának vizsgálata hatvan év feletti nők körében. Acta Academiae Paedagogicae Agriensis Nova Series: Sectio Sport. 5-16.

Fenyves, V., Orbán, I., Könyves, E., Nagy, A. \& Sándor, F (2014). Economical aspects of thermal and medical tourism. Apstract - applied studies in Agribusiness and Commerce 8.(4.). 77-84.

Fenyves, V., Szabados, Gy. \& Bács, Z. (2019). The Study of motivational factors among participants in a particular sports festival. Sea: Practical Application of Science 7.(1.). 17-22.

Fenyves, V., Dajnoki, K., Máté, D. \& Baji-Gál, K. (2016). Examination Of The Solvency Of Enterprises Dealing With Accommodation Service Providing In The Northern Great Plain Region Sea: Practical Application of Science 4. (2,)197-203
Fehér, A., Bácsné, B. É., Müller, A. \& Szakály, Z. (2019). MPAM-R modellekkel kapcsolatos kutatások rendszerezése - Szakirodalmi áttekintés. In Fehér András; Szakály, Zoltán (szerk.): Egészségpiaci kutatások. Debreceni Egyetem Gazdaságtudományi Kar, Debrecen. 173-183.

Field, T., Diego, M. \& Cullen, C. (2004). Carpal tunnel syndrome symptoms are lessened following massage therapy. J Bodyw Mov Ther. 81914.10.1016/S1360-8592(03)00064-0

Field, T., Diego, M. \& Hernandez-Reif, M. (2007). Hand arthritis pain is reduced by massage therapy. J Bodyw Mov Ther. 1112124.10.1016/j.jbmt.2006.09.002

Fodor, M. \& Szilágyi, Tibor, P. (2014). A wellness, mint egészségmegőrző projekt lehetőségei a régiók fejlesztésében fogyasztói primer adatok tükrében. Vállalkozásfejlesztés a XXI. században, Budapest. 281-290.

Gaál, Sz., Szigeti, P., Dimitra, P., Matthew, G. \& Ewout, van G. (2011). Major challenges ahead for Hungarian healthcare. British Medical Journal; 343.

Hidvégi, P., Biró, M., Lenténé, P.A., Pucsok, J.M., Tatár, A. \& Bárdos, K. (2019). Wellness szolgáltatást igénybevevők felmérése az Észak-alföldi régióban In Balogh, László (szerk.) Sokoldalú sporttudomány. Debrecen, Magyarország: Debreceni Egyetem Sporttudományi Koordinációs Intézet, Debrecen.1-8.,

Hidvégi, P., Bíró, M. \& Müller, A. (2015). A rekreáció elmélete és módszertana 2.: Egészségfejlesztés. Eger, Magyarország: Líceum Kiadó, 25.

Horkay, B., Lenténém P.A. \& Biró, M. (2018). The supply elements and the recreational possibilities in the city and in the countryside In Jaromír, Šimonek; Beáta, Dobay (szerk.) Sport science in motion: proceedings from the scientific conference. Mozgásban a sporttudomány: válogatott tanulmányok a konferenciáról, Komárno, Szlovákia : Univerzita J. Selyeho, 330-339. ,

Hymel, G.M. \& Rich G.J. (2013). Health psychology as a context for massage therapy: A conceptual model with CAM as mediator. Journal of Bodywork and Movement Therapies. 
http://www.sciencedirect.com/science/article/pi i/S1360859213001216

Juhász, I., Kopkáné, P.J., Kiszela, K., Bíró, M., Müller, A. \& Révész, L. (2015). Időskorúak rekreációs fizikai aktivitásának hatása a kardiorespiratorikus rendszerre Magyar Sporttudományi Szemle, 16. 4-8.,

Kerényi, E., Müller, A., Szabó, R. \& Mosonyi, A. (2009). Analysis of Agárd, Komárom and Papa’s Thermal and Experiences bath according the guest's satisfaction. In Kerényi, Erika (szerk.) Egésæségügyi marketing és telekommunikáció. Mátraháza.56-67.

Krohn, M., Listing, M., Tjahjono, G., Reisshauer, A., Peters, E., Klapp, B.E. \& Rauchfuss M. (2010). Depression, mood, stress, and Th1/Th2 immune balance in primary breast cancer patients undergoing classical massage therapy. Support Care Cancer. Sep;19(9).1303-11.

Lengyel, A. (2019). A mindfulness és liminalitás felértékelődése: spirituális elvonulási központok, a fenntartható jövő desztinációi? Turiz̨mus Bulletin 19. 14-24.

Lengyel, A. (2015): Extending tourism's role in the tourism - meditation - creativity - innovation - sustainability trajectory. In Dunay, Anna (szerk.) Proceedings of the 5th International Conference on Management 2015: Management, Leadership and Strategy for SMEs' Competitiveness. Gödöllő, Szent István Egyetemi Kiadó. 543-548.

Lengyel, A., Kalmárné, R. Cs. \& Szabó, A. P. (2018). Mindfulness-based tourism products: market potential and sustainability implications. In Dinya, László; Baranyi, Aranka (szerk.) XVI. Nemzetközi Tudományos Napok: „Fenntarthatósági kihívások és válaszok" - A Tudományos Napok Publikációi. Gyöngyös, Magyarország: EKE Líceum Kiadó, 1153-1162.

Lengyel, A. \& Kalmárné, R. Cs. (2018). Towards health and wholeness: physical and psychological effects of mindfulness. In Jaromír, Šimonek; Beáta, Dobay (szerk.) Sport science in motion: proceedings from the scientific conference. Mozgásban a sporttudomány: válogatott tanulmányok a konferenciáról.Komárno, Szlovákia : Univerzita J. Selyeho286-298.

Lenténé, P.A., Biró, M., Hidvégi P., Molnár A., Lente L. \& Pucsok J.M. (2019). Analysis of the North Great Plain Region's Accommodation Supply with Special Focus on Sport and Wellness Element Geosport For Society, 10. 15-24.

Lenténé, P.A., Biró, M., Dobay, B. \& Pucsok, J.M. (2018). A szabadidő sportolás kínálati elemeinek, és szolgáltatásainak vizsgálata Magyarország észak-alföldi régiójának szállodáiban. Selye e-studies 9: 1.13-21.

Laoues, C. N., Müller, A. \& Bácsné, B. É. (2019 a). Fogyatékossággal élőgyerekek sport-fogyasztási szokásainak vizsgálata az akadálymentesített kínálati elemek tükrében. Economica (Szolnok) 10: 1. 21-29.

Laoues, C. N., Müller, A. \& Bácsné, B. É. (2019 b). Comparative analysis of active and passive recreational consumption habits of disabled children living in the Northern Great Plain region. Különleges Bánásmód 5: 131-39. DOI 10.18458/KB.2019.1.31

Laoues, C.N., Dobay, B. \& Müller, A. (2019c). Examination of the leisure time-related consumption habits of young people with disabilities with special emphasis on sports. Selye e-studies 10: 2. 34-45.

Mező, K. (2012). Rendezvényszervezési alapismeretek. In Mező, Ferenc (szerk.) Tehetségkoordinátorok kérikeönyve. Debrecen, K+F Stúdió Kft., 131140.

Mező, F. \& Mező, K. (2017). A szülők nevelési stílusa és hatásuk a gyermekek magatartására: a családból való kimenekülés pedagógiai okai. In Vargáné, Nagy Anikó (szerk.). Családi nevelés 2. Debrecen, Didakt Kft., 50-66.

Moyer, C., Rounds, M. \& Hannum J.W. (2004). A meta-analysis of massage therapy research. Psychol Bull. 13013-18.10.1037/0033-2909.130.1.3. 
Müller, A., Boda, E., Ráthonyi, G., Ráthonyi-Odor, K., Barcsák, B., Könyves, E., Biró, M., Dobay, B. \& Bendíkova E. (2016). Analysis of the Cavebath of Miskolctapolca's brand elements and guests satisfaction. Applied Studies In Agribusiness And Commerce (Apstract), 10:(4-5), 157-162.

Müller A., Ráthonyi, G., Bíró, M., Ráthonyi-Ódor, K., Bács, Z., Ács, P., Hegyi, G. \& Bácsné Bába É. (2018). The effect of complex climate therapy on rehabilitation results of elderly asthmatic and chronic obstructive airways disease (COPD) patients European Journal Of Integrative Medicine, 106114.

Müller, A. \& Bácsné, B.É.(2018). Az egészséges életmód és a sport kapcsolata. Létavértes, Magyarország: Létavértes SC '97 Egyesület, 96.

Müller, A., Szabó, R., Kerényi, E. \& Mosonyi, A. (2009). Fürdőkutatás a Közép-dunántúli régióban. Acta academiae paedagogicae agriensis nova series: sectio sport $36.77-87$..

Müller, A., Bácsné, B. É., Pfau, C., Molnár, A. \& Laoues, C.N. (2019): Extrém sportfogyasztás vizsgálata egy kutatás tükrében. International Journal of Engineering and Management Sciences / Müszaki és Menedssment Tudományi Közlemények 3: 4. 135 142.

Müller, A., Barcsák B. \& Boda E.J. (2016). Health tourism the cavebath of Miskolctapolca. In: György, Juhász; Enikő, Korcsmáros; Erika,
Huszárik (szerk.). Korszerü szemlélet a tudományban és az oktatásban. Gazdaságtudományi szeekció. Komárno, Szlovákia : Selye János Egyetem. 233-245.

Müller, A. \& Kerényi, E. (2009). Trendek és fogyasztói magatartás az egészségügyben. In Kerényi, Erika (szerk.) Egészségügyi marketing és telekommunikáció. Mátraháza.11-19.

Müller, A. \& Könyves, E. (2006). Az egészségturizmus lehetőségei az Észak-alföldi régióban. Acta Academiae Paedagogicae Agriensis Nova Series: Sectio Sport 33. 132-143.

Perlman, A., Sabina, A., Williams, A.L., Niike, V.Y. \& Katz, D.L. (2006). Massage therapy for osteoarthritis of the knee: a randomized controlled trial. PubMed. 166(22):2533-8.

Robertson, A., Watt, J.M. \& Galloway, S.D. (2002): Effects of leg massage on recovery from high intensity cycling exercise. Br J Sports Med. 2004. 382173-176.10.1136/bjsm.2002.003186

Szira, Z. \& Lajos A. (2005). Health Consciousness in the Life Style and Scale of Values of the Hungarian Young People. In Annals of the Polish Association of Agricultural and Agribusiness Economists. Vol. VII. No. 6. Warsaw-Poznan 2-16

Tidus, P. (2000). A review of human massage therapy: assessing effectiveness primarily from empirical data in the human species AAEP Proceedings. AAEP, 2000. 46302-305. 